\title{
Weapons of Mass Persuasion: Marketing the War against Iraq
}

\author{
Paul Rutherford
}

Toronto: University of Toronto Press, Inc., 2004. 226 pages.

The concept of a public body deluded into believing whatever its leaders assert as truth might seem to recall Marxist theories of media and society. 
But this is an element of the reality painted by Paul Rutherford in his Weapons of Mass Persuasion: Marketing the War against Iraq, in which he examines Washington's promotion of the war and its effectiveness in winning public support despite misinformation.

Public opinion has been key to maintaining support for the war and the tremendous amount of money that it continues to pull out of the American economy. Rutherford investigates the marketing strategy, illustrates its effects, and explores the significance of the experiment. His analysis provides an insightful look into how Washington was able to convince the American people of the false threat of "weapons of mass destruction" and raises important questions about what the Bush administration's "persuasion” experiment means for American democracy.

The author dedicates the first three chapters to analyzing how the "weapons of mass persuasion" were deployed. However, the heart of his study lies in the effects of those "weapons" on individuals and society. His research is centered in Canada and draws from its government and press. This makes it difficult to discern who is the focus of his analysis - is it Canadians, Americans, the Middle East, or the world at large?

At the start, the reader is introduced to a panel of 20 Canadian citizens of varying backgrounds, living in and around Toronto, whom Rutherford has interviewed for "consumer voices." These voices offer a sense of the impact of translating huge events and decisions into personal experience. But as they are Canadian (not American) consumers of media products, this becomes a little problematic when discussing the effects of propaganda. After all, the most significant target of Washington's pro-war propaganda is American public opinion.

His fifth chapter relies almost entirely on "consumer voices" to illustrate how people construct their own meanings from what they see and read about the world. On an individual basis, this is effective - mass media scholars have theorized endlessly about how a viewer receives a mediated message and forms a perception of reality based on his or her experience, culture, and time frame. Rutherford explains, for instance, how one viewer relied on his personal knowledge of the Middle East to filter what he saw on television, and another read widely before the war on the American case for invasion. But these consumers are all Canadians, and their views, even of CNN or Fox News, will differ because of their cultural distance. His panel saw those networks' messages as particularly American, and therefore manipulative - a panel of American voices might tell a different story and paint a more accurate picture of the effects of such marketing. 
But even for his panel, the seduction of such repeated messages as "liberate Iraq" and "spread democracy" was strong enough to sway some of them, thereby showing the effectiveness of the marketing campaign, which Rutherford explores earlier. Marketing is an apt metaphor for a campaign designed to sway a body politic toward a certain goal, and Rutherford takes the time to explain it fully. He describes the nature of effective marketing advertising, for example, that entertains, titillates, and appeals to familiar, pop-culture storylines - and sets the stage for explaining the marketing of "Iraq the movie" as propaganda, an assertion of supposed facts rather than an argument. Polls taken well after the war began revealed that a majority of Americans still believed the Bush administration's earlier assertions of, for instance, an Iraq-al-Qaeda link or the "imminent threat" of weapons of mass destruction (WMDs).

In fact, Rutherford discusses these key selling points in chapter 2: the threat that Iraq posed to the United States and to peace in the Middle East and to the world, and the "liberation" of Iraq from Saddam's tyranny. This was the fall and winter of 2002-03, when American airwaves were thick with the debate over weapons inspections. Although the United Nations was not swayed by Colin Powell's February 2003 attempt to gain its support, much of the American public considered his assertions that "Saddam Hussein has biological weapons” legitimate.

The success of the propaganda, as the author explains in chapter 3, was due to the role played by the mainstream media, which co-opted such Pentagon terminology as "shock and awe," "regime change," and several other military phrases. Embedded reporters, as well as analysts and anchors, served as what author and media critic Norman Solomon called, during the October 2001 strike on Afghanistan, "stenographers for the Pentagon” rather than true journalists. They served the purpose of the Pentagon's war plan, which, Rutherford argues, was to make the war appealing by whitewashing negative aspects while increasing the public's fear of a "credible enemy." Here, he begins to examine the marketing campaign's effects. With the 24hour availability of Pentagon-scripted news coverage - exciting, movie-like, and untainted by such downers as civilian casualties - viewers were shunted away from the full story and lured into the story that the Bush administration wanted them to see.

The author's analysis of the "weapons of mass persuasion" culminates in the ominous-sounding "propaganda state," in which insidious marketing measures are paraded as popular culture in order to manage the public's fears and desires while maintaining the illusion of true democracy. He states that 
the propaganda state receded with the April 2003 fall of Baghdad and the capture of Saddam, but a little more hindsight by early 2005 shows otherwise.

If the Bush administration had to engage in damage control after its failure to locate any WMDs and the loss of thousands of Iraqi and American lives, it did so successfully enough to ensure it another 4-year term in office. It has fought back in the public arena by pointing to the January 30, 2005, Iraqi elections as a sign of success and asserting that it does not matter if there were no WMDs because the world is now safer. Rutherford's postscript in the summer/fall of 2003 details the effect of the collapse of Washington's marketing exercise, but Bush's November 2004 victory shows that its efforts were not in vain.

At the very start of his book, Rutherford declares his own anti-war perspective, based on the international illegitimacy of the Iraq invasion. Although this view, as well as the mostly informed and generally anti-war perspectives of the panel, colors the book, his analysis can still serve as a pertinent contemporary examination of relationships between the government, the media, and the public. It would be intriguing to follow the same analysis after some major policy or administration change - perhaps after the end of the so-called "war on terror," if an end is possible. Such a study might be better able to illuminate the true effects of mass persuasion on a democracy.

Ayesha Ahmad Community Reporter, The Gazette Prince George’s County, Maryland 